\title{
Orientation and position of substrata have large effects on epibiotic assemblages
}

\author{
T. M. Glasby* ${ }^{*}$ S. D. Connell ${ }^{* *}$ \\ Centre for Research on Ecological Impacts of Coastal Cities, Marine Ecology Laboratories, A11, University of Sydney, \\ New South Wales 2006, Australia
}

\begin{abstract}
The orientation and position of hard substrata used to test ecological hypotheses about sessile marine plants and animals have often been based on logistical convenience. Much of our understanding of the ecology of epibiota is based on artificial habitats (particularly the undersides of floating pontoons), despite epibiotic organisms being an important and conspicuous component of natural hard substrata (e.g. vertical surfaces of rocky reefs). We assessed the model that pontoons act as inherently different habitats from rocky reefs, independent of the size, shape, age and composition of the substratum, by comparing the development of epibiota on settlement panels in the 2 habitats. Panels orientated the same way on pontoons and rocky reefs were found to support different epibiotic assemblages, and panels orientated differently (vertical vs horizontal undersides) also supported different assemblages. Position (reef vs pontoon) affected a broader range of taxa than did orientation, although effects of each were generally inconsistent among sites. Covers of spirorbid polychaetes, encrusting bryozoans, mussels, colonial ascidians and red filamentous algae were affected greatly by position. Tubiculous polychaetes, barnacles and species of brown and green filamentous algae were influenced by orientation. This study provides experimental evidence that pontoons are fundamentally different habitats from natural rocky reefs. The results highlight the need for caution in the use and interpretation of studies using artificial habitats when testing hypotheses about naturally occurring assemblages.
\end{abstract}

KEY WORDS: Fouling $\cdot$ Recruitment $\cdot$ Hard substrata $\cdot$ Artificial habitats $\cdot$ Experiment $\cdot$ Subtidal

\section{INTRODUCTION}

It is common practice to use artificial substrata to test hypotheses derived from ecological theory. Such substrata are useful because (1) they provide identical structures from which replicate observations can be made, and (2) their uniformity minimises any unquantified and unknown physical differences (e.g. size, shape and composition) that occur among replicate

Present addresses:

*The Ecology Lab Pty Ltd, 4 Green Street, Brookvale, New South Wales 2100, Australia.

E-mail: tglasby@theecologylab.com.au

** Department of Environmental Biology, University of Adelaide, Adelaide, South Australia 5005, Australia surfaces in natural habitats and which may cause variation in assemblages. This greater control over experimental conditions has strong appeal to ecologists and is widely used in terrestrial ecology (e.g. artificial nests for birds: Nour et al. 1993, Huhta et al. 1998; artificial tree-holes for insect larvae: Paradise 1998; artificial boulders for reptiles: Reading 1997), freshwater ecology (artificial boulders for invertebrates: Downes et al. 1998) and marine ecology (artificial reefs for fish and crustaceans: Jones 1991, Eggleston et al. 1997; artificial seagrass for fish and crustaceans: Bell et al. 1985; urban structures or settlement panels for sessile plants and animals: e.g. Wilson 1925, Aleem 1957, Sutherland 1974, Osman 1977, Kay \& Keough 1981).

Despite their utility, the value of artificial substrata to the development of ecological theory may depend on 
the extent to which understanding assemblages on these substrata improves our knowledge of naturally occurring assemblages. While it is widely accepted that studies using artificial substrata provide insights into the kinds of ecological responses that can be expected under particular conditions, man-made substrata may not always act as proxies for natural substrata (Kennelly 1983, Keough 1984, Doherty \& Fowler 1994, Butler \& Rotella 1998, King et al. 1999). Studies involving artificial substrata (or indeed entire habitats) may be of limited value because the results are specific to the particular conditions created by the artificial substratum or habitat. If this is the case, researchers should consider carefully the potential artefacts of using artificial substrata or habitats to obtain information about naturally occurring assemblages.

Marine ecologists have a long history of using artificial substrata and habitats (e.g. pilings and pontoons) to test hypotheses about sessile plants and invertebrates (e.g. Coe 1932, McDougall 1943, Sutherland 1974, Osman 1977, Keough 1984, Osman \& Whitlatch 1995). These epibiotic assemblages are an important component of rocky reefs; they provide food and shelter for a wide variety of invertebrates and fishes (e.g. Choat \& Kingett 1982, Holbrook et al. 1990) and can be used to categorise and identify major subtidal habitats (Underwood et al. 1991). Much of the present understanding of the ecology of epibiotic assemblages is based on studies done on pier pilings and floating pontoons. Such studies typically involve suspending settlement panels from floating rafts or pontoons to test the effects of particular factors on the development of epibiotic assemblages (e.g. Wisely 1959, Sutherland \& Karlson 1977, Dean \& Hurd 1980, Greene \& Schoener 1982, Schmidt \& Warner 1984, Osman \& Whitlatch 1995, Brown \& Swearingen 1998). Although these studies did not explicitly propose to explain phenomena that occur on natural hard substrata in natural habitats, their results may often be used to identify the types and characteristics of processes that determine the population dynamics of epibiotic assemblages.

Unfortunately, there is little understanding of the extent to which these studies can be generalised to rocky reefs. Many researchers have warned that characteristics of settlement panels may influence the establishment of epibiotic assemblages (e.g. Jackson 1977, Osman 1977, 1982, Keough 1983), but rarely has settlement on panels been compared directly to settlement on rocky reefs (see Kennelly 1983). When this has been done, the panels typically have been attached to rocky reefs. Direct comparisons of assemblages on panels attached to artificial structures, such as pontoons and pilings, versus panels in natural hard substratum habitats have not been made. It is certainly possible that some processes which influence the de- velopment of epibiotic assemblages may be identical on pontoons and rocky reefs. Nevertheless, it would be prudent to assess how our present understanding of the ecology of epibiotic assemblages on pontoons relates to rocky reef habitats. There is mounting evidence to suggest that such information is needed, because large differences between artificial and natural habitats have become apparent (Keough 1984, Butler \& Connolly 1996, Connell \& Glasby 1999, Glasby 1999a, Connell 2000).

Recent work has demonstrated that the structure of epibiotic assemblages on vertical surfaces differs among various kinds of urban structures (i.e. pontoons, pilings, retaining walls) and rocky reefs, with the greatest difference occurring between rocky reefs and floating pontoons (Connell \& Glasby 1999). Moreover, the structure of assemblages on vertical surfaces of pontoons differs markedly from those attached to the horizontal undersides (Connell 1999). Although differences between surfaces of these orientations have been demonstrated also in rocky reef habitats (Glasby 2000), these were unlike those described for pontoons in the same area. Specifically, differences between orientations on pontoons were caused by a group of filamentous algae and 1 species of bryozoan, whereas on rocky reefs, differences were caused by numerous species of algae, bryozoans, ascidians and polychaetes. Pontoons may act as very different habitats, or even novel habitats for epibiotic organisms. We know, for example, that proximity to the seafloor and shading can markedly influence the development of epibiotic assemblages (Glasby 1999b) and so influence the ecology of pontoon and reef habitats which occur at different distances from the seafloor and are typically shaded to different extents.

This study assessed the general model that pontoons are inherently different habitats from rocky reefs, independent of the size, shape, age and composition of the substrata in those habitats. We predicted that the same surfaces (in terms of their size, shape, age and composition) would support different epibiotic assemblages when orientated the same way on pontoons and rocky reefs. Furthermore, surfaces orientated differently (vertical vs horizontal undersides) would support different assemblages, but the differences in structure of assemblages between orientations on pontoons would not be consistent with those on rocky reefs.

\section{MATERIALS AND METHODS}

Settlement panels were deployed at 3 sites (Connell \& Glasby 1999: Site 2 including $200 \mathrm{~m}$ east), 200 m apart, in Middle Harbour $\left(33^{\circ} 48^{\prime} \mathrm{S}, 151^{\circ} 14^{\prime} \mathrm{E}\right)$, the northern part of Sydney Harbour, in June (winter) 
1998. Panels were $15 \times 15 \mathrm{~cm}$ and constructed of concrete (a material similar to many pontoons). Five replicate panels orientated vertically and 5 orientated horizontally (facing downwards) were attached to rocky reefs and pontoons at each site. Rocky reefs in Middle Harbour extend about $5 \mathrm{~m}$ from the shore and reach a maximum depth of $\sim 4 \mathrm{~m}$ at low tide. Pontoons associated with residential houses typically are 5 to $10 \mathrm{~m}$ from the shore and $\sim 4 \mathrm{~m}$ above reefs or the sandy seafloor. The area is sheltered from oceanic swell and is approximately $5 \mathrm{~km}$ from the open ocean. Tidal amplitude is $\sim 1.5 \mathrm{~m}$.

Panels on pontoons were attached to the outer edges on 2 sides of each pontoon $(3 \times 4 \mathrm{~m})$ at a depth of approximately $25 \mathrm{~cm}$. PVC pipe (90 cm diameter) was suspended securely under a ledge of the pontoon with a fabric strap which passed through the pipe and was fastened to the upper surface of the pontoon. PVC brackets were glued onto the backs of panels, and these were bolted to the pipes. Replicate panels, separated by $50 \mathrm{~cm}$ on each pipe, were arranged regularly such that there were vertical and horizontal panels side by side on each of the 2 pipes per pontoon.

Panels on rocky reef were adjacent to the pontoons (closer to the shore), but not directly shaded by them. Aluminium beams $\left(32 \times 32 \mathrm{~mm}, 90^{\circ}\right.$ angle $)$ were drilled into the rocky reef at a depth of $1.5 \mathrm{~m}$ below mean low-water springs such that they were subtidal permanently. PVC brackets were glued onto the backs of panels and these were bolted to the beams (as in Glasby 1998) so that panels were $\sim 15 \mathrm{~cm}$ from the substratum. Thus, panels on the reef were not integral with the substratum and so were similar to panels on pontoons in this regard. Vertical and horizontal panels were attached to separate beams, but the beams were arranged close together in pairs such that a vertical panel was not further than $50 \mathrm{~cm}$ from a horizontal panel (i.e. similar to panels on pontoons). Replicates on the same beam were $90 \mathrm{~cm}$ apart and replicates (of the same treatments) on different beams were 3 to $4 \mathrm{~m}$ apart. We believed it unlikely that the slight difference in spacing of replicate panels on reefs and pontoons would influence the results of this study. The supply of larvae is patchy, and therefore unlikely to cause consistent differences among treatments that are spaced regularly.

Panels were collected in summer after 7 mo of submergence, then refrigerated at $<5^{\circ} \mathrm{C}$ until sampled (within $6 \mathrm{~d}$ of collection) under a dissecting microscope. Only the fronts of panels were sampled, i.e. the outward-facing surfaces of vertical panels on pontoons, the side facing away from the shore on vertical panels attached to rocky reefs and the undersides of horizontal panels on reefs and pontoons. Primary cover (organisms attached directly to the panel) and secondary cover (organisms attached to primary cover) were estimated for sessile organisms using 64 regularly spaced points in a $13 \times 13 \mathrm{~cm}$ grid (i.e. a $1 \mathrm{~cm}$ border around each panel was not sampled to avoid 'edge effects'). Taxa on the fronts of panels, but not under a point, were assigned a cover of $0.5 \%$. Species of filamentous algae were combined because often many of these species were present under a point and it was impossible to allocate the point to just 1 species.

To compare covers of sessile organisms among treatments, percentage cover data for primary and secondary covers of each taxon were combined for univariate (ANOVA) and non-parametric multivariate (PRIMER package) analyses. If variances were heterogeneous (Cochran's $C$-test, $\mathrm{p}<0.05)$, data were arcsine transformed for univariate analyses, but variances could not always be made homogeneous. For balanced designs, ANOVA is relatively robust to heterogeneous variances (Box 1953), but significant results at the level of $\mathrm{p}<0.05$ should perhaps be interpreted with some caution. Means were compared using Student-Newman-Keuls (SNK) tests. Multivariate data were fourthroot transformed, and Bray-Curtis similarity matrices were calculated. Data were presented graphically using non-metric multi-dimensional scaling (nMDS) ordinations. One-way analyses of similarities (ANOSIM; Clarke \& Green 1988) and multiple pairwise comparisons tested for differences in assemblages among treatments at each site. The significance level for pairwise tests was reduced from $\alpha=0.05$ to $\alpha=0.01$ to adjust for 4 multiple comparisons (i.e. 0.05/4; Bonferroni procedure).

Two vertical panels were lost from Site 1 and, to maintain balanced univariate analyses, these values were replaced by the mean of the remaining replicates at that site and the residual degrees of freedom, mean square estimates and $F$-ratios adjusted accordingly for each taxon (Underwood 1981).

\section{RESULTS}

Multivariate analyses were used to compare the percentage covers of bare space and 44 taxa among panels (including polychaetes, bryozoans, barnacles, bivalves, sponges, ascidians, algae, cyanobacteria and the coral Culicia sp.). Most taxa were identified to genus or species, but polychaetes were identified only to family, and there were 6 unidentified sponges and 2 unidentified solitary ascidians.

Large multivariate differences in the structure of assemblages were apparent between positions (reef vs pontoons) and orientations (vertical vs horizontal) (Fig. 1). That is, assemblages on panels on pontoons (Fig. 1: squares) are located to the left of assemblages on rocky reefs (Fig. 1: circles) in the nMDS plot. Simi- 


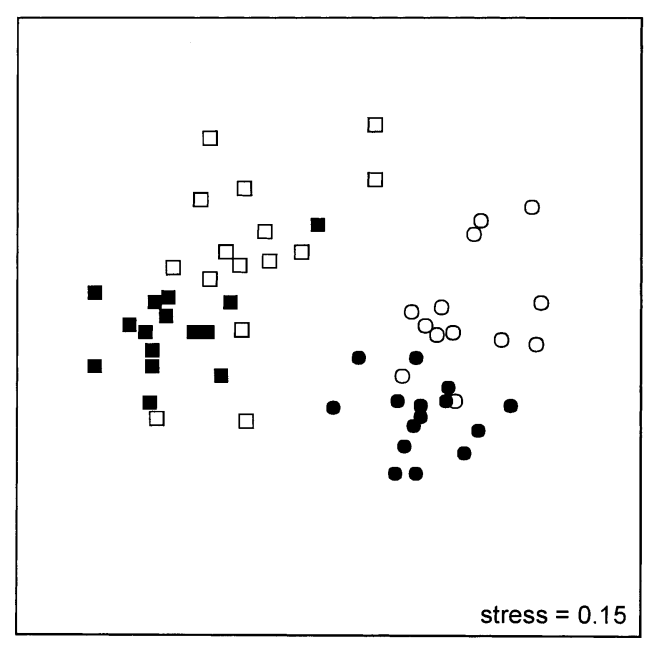

Fig. 1. nMDS plot of assemblages on vertical $(0,0)$ and horizontal undersides $(\bullet, \boldsymbol{\bullet})$ of concrete plates positioned on rocky reef $(0, \bullet)$ and pontoons $(\square, \boldsymbol{\square})$ at 3 sites. $\mathrm{n}=5$ per treatment per site, with 2 missing replicates for vertical reef plates

larly, assemblages on horizontal surfaces (black symbols in Fig. 1) are generally separated from those on vertical surfaces (open symbols).

Pairwise comparisons indicated that the composition of assemblages on panels differed significantly between vertical and horizontal surfaces at 2 of the 3 sites and between rocky reefs and pontoons at all sites (Table 1). There tended to be greater differences in assemblages between positions than between orientations, $\mathrm{R}$ values were generally larger for tests of the effect of position (Table 1), and points on the nMDS plot were separated more by position (Fig. 1). Comparisons of Bray-Curtis dissimilarity percentages supported this interpretation. Dissimilarities between positions for the 3 sites were 56.5,55.3,47.0, and dissimilarities between orientations were $52.2,45.8,41.3$ (i.e. at each site, positions tended to be more dissimilar than orientations).

All taxa which dominated space on panels revealed large variation between orientations and/or positions,

Table $1 . \mathrm{R}$ values from multivariate pairwise comparisons of assemblages on vertical plates (V) and horizontal undersides $(\mathrm{H})$ on reef $(\mathrm{R})$ and pontoon $(\mathrm{P})$ for 3 sites in Sydney Harbour. All comparisons significantly different $(p<0.01)$, except those marked $^{\text {ns }}(p>0.01)$

\begin{tabular}{|lccc|}
\hline Comparison & Site 1 & Site 2 & Site 3 \\
\hline Reef: V vs H & 1.000 & 0.548 & $0.336^{\mathrm{ns}}$ \\
Pontoon: V vs H & 0.760 & 0.448 & $0.300^{\mathrm{ns}}$ \\
Vertical: R vs P & 0.916 & 0.972 & 0.868 \\
Horizontal: R vs P & 1.000 & 1.000 & 0.848 \\
\hline
\end{tabular}

Table 2. Dominant taxa (accounting for, on average, $80 \%$ of cover on plates) on vertical and horizontal undersides of plates on reef and pontoons. Percentages are means $( \pm \mathrm{SE})$ across 3 sites

\begin{tabular}{|ll|}
\hline Orientation & Dominant taxa \\
\hline Reef & \\
& Spirorbids $(38 \% \pm 5)$, \\
& Conopeum seurati $(21 \% \pm 4)$, \\
& Serpulids $(12 \% \pm 2)$, \\
Horizontal & Ceramiales $(10 \% \pm 4)$ \\
& Serpulids $(25 \% \pm 3)$, \\
& Conopeum seurati $(23 \% \pm 4)$, \\
& Balanus variegatus $(22 \% \pm 6)$, \\
& Cryptosula pallasiana $(13 \% \pm 2)$ \\
Pontoon & \\
Vertical & Conopeum seurati $(28 \% \pm 5)$, \\
& Balanus variegatus $(21 \% \pm 3)$, \\
& Mytilus edulis $(19 \% \pm 5)$, \\
& Diplosoma listerianum $(7 \% \pm 1)$, \\
Horizontal & Serpulids $(7 \% \pm 1)$ \\
& Balanus variegatus $(41 \% \pm 6)$, \\
& Conopeum seurati $(19 \% \pm 3)$, \\
& Mytilus edulis $(18 \% \pm 5)$, \\
& Serpulids (8\% $\% 1)$ \\
\hline
\end{tabular}

except the encrusting bryozoan Conopeum seurati (Table 2). Position of panels affected a broader range of taxa than did orientation of panels (Table 3) and effects of both factors generally were inconsistent among sites. Taxa that were most clearly affected by position are presented in Fig. 2, and those generally affected by orientation of panels in Fig. 3. Interactions between position and orientation were uncommon, but did occur consistently among sites for spirorbid and serpulid polychaetes (Table 3: a,g). Spirorbids always

Table 3. Summary of results of univariate analyses of variance for dominant taxa (identified in Table 2). $\mathrm{P}=$ position (fixed factor), $\mathrm{O}=$ orientation (fixed), $\mathrm{S}=$ site (random). Main effects are not reported because interactions were significant (Underwood 1981). ns: $\mathrm{p}>0.05 ;{ }^{*} \mathrm{p}<0.05 ;^{* *} \mathrm{p}<0.01{ }^{* * *} \mathrm{p}<0.001$

\begin{tabular}{|c|c|c|c|c|}
\hline Taxon & $\mathrm{P} \times \mathrm{S}$ & $\mathrm{O} \times \mathrm{S}$ & $\mathrm{P} \times \mathrm{O}$ & $\mathrm{P} \times \mathrm{O} \times \mathrm{S}$ \\
\hline a: Spirorbid polychaetes ${ }^{a}$ & * & ns & $* *$ & ns \\
\hline b: Cryptosula pallasiana ${ }^{\mathrm{b}}$ & * & $*$ & ns & ns \\
\hline c: Conopeum seurati & $*$ & $* *$ & ns & ns \\
\hline $\mathrm{d}:$ Mytilus edulis ${ }^{\mathrm{a}}$ & $* * *$ & ns & ns & ns \\
\hline e: Diplosoma listerianum & ${ }^{*}$ & ns & ns & ns \\
\hline f: Ceramiales ${ }^{a}$ & * & ns & ns & ns \\
\hline g: Serpulid polychaetes ${ }^{\mathrm{b}}$ & ns & ns & $*$ & ns \\
\hline h: Balanus variegatus ${ }^{\mathrm{b}}$ & $* * *$ & ns & ns & $*$ \\
\hline i: Feldmania sp. ${ }^{\mathrm{a}}$ & ns & $* * *$ & ns & ns \\
\hline j: Cladophorales ${ }^{\mathrm{a}, \mathrm{b}}$ & ns & ns & ns & * \\
\hline
\end{tabular}


(a) Spirorbids

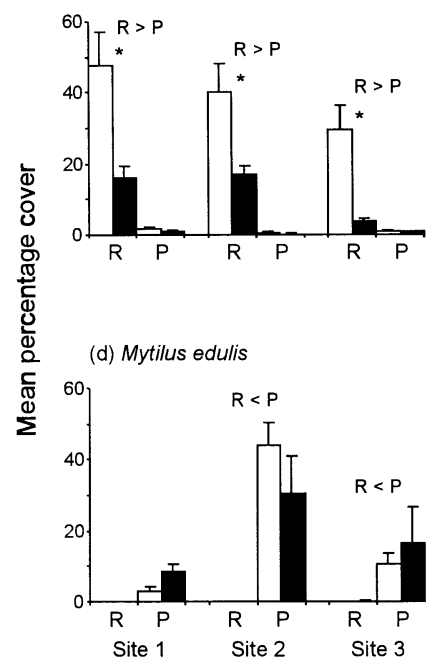

(b) Cryptosula pallasiana

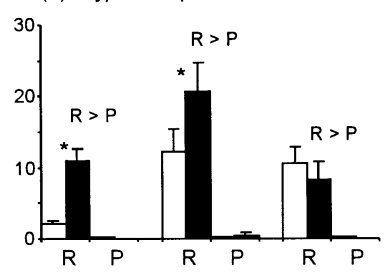

(e) Diplosoma listerianum

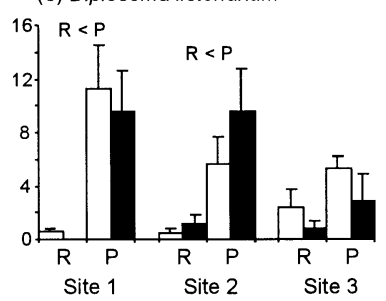

were rare on pontoons compared to reefs, and on reefs they were significantly more abundant on vertical panels than on horizontal undersides (Fig. 2a, Table 3: a). Conversely, on rocky reefs, serpulid polychaetes were significantly more abundant on the undersides of panels than on vertical surfaces (Fig. 3a, Table 3: g). Differences in abundances of serpulids between reefs and pontoons occurred only for the undersides of panels (reef > pontoon, Fig. 3a).

The cover of the encrusting bryozoan Cryptosula pallasiana was greater on reefs than on pontoons at all sites (Fig. 2b, Table 3: b). Patterns for Conopeum seurati were inconsistent, but it was more abundant on pontoons than reefs at 1 site (Fig. 2c, Table 3: c).

(a) Serpulids

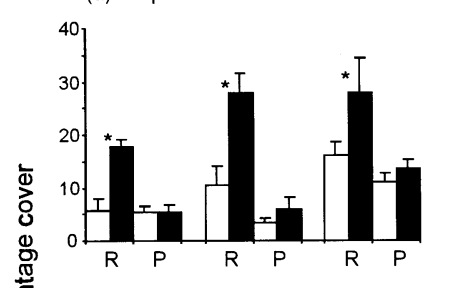

(c) Feldmania sp

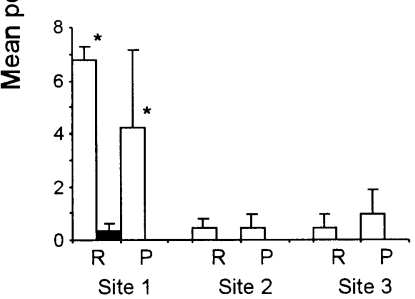

(b) Balanus variegatus

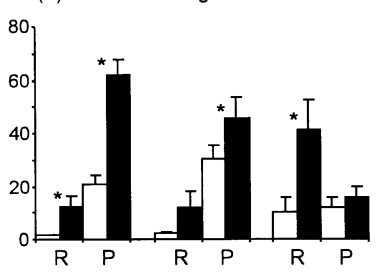

(d) Cladophorales

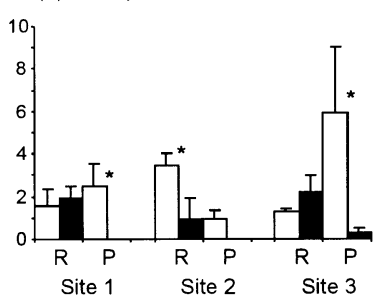

Fig. 3. Percentage cover (+SE) of taxa which differed primarily according to orientation (i.e. vertical vs horizontal undersides). Open bars: vertical; black bars: horizontal undersides; R: reef; P: pontoon. Further details as for Fig. 2

(c) Conopeum seurati

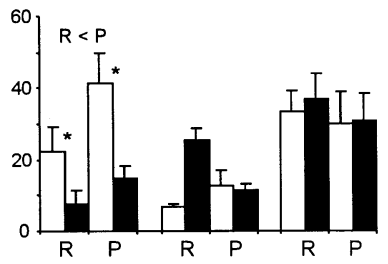

Fig. 2. Percentage cover (+SE) of taxa which differed primarily according to position (i.e. reef vs pontoon). Open bars: vertical; black bars: horizontal undersides; R: reef; P: pontoon. $\mathrm{n}=5$, except for vertical plates on reef at Site $1(n=3)$. SNK results for significant Position $\times$ Site interactions are shown above graphs. ${ }^{*}$ Significant difference between orientations in that position

Despite the inconsistent effects of position on other taxa, some patterns emerged. Mussels (Mytilus edulis) and the colonial ascidian Diplosoma listerianum tended to be more abundant on pontoons than on reefs (Fig. 2d,e, Table 3: d,e), whereas red filamentous algae (grouped here as Ceramiales) generally showed the opposite pattern (Fig. 2f, Table 3: f). The cover of the globally distributed bryozoan Bugula neritina was relatively sparse on reefs $(0.3 \% \pm 0.1 \mathrm{SE})$ compared to pontoons $(3.8 \% \pm 0.8 \mathrm{SE})$ across all sites. Similarly, the solitary ascidian Styela plicata, another globally distributed species, tended to be more abundant on panels attached to pontoons $(5.3 \% \pm 1.5 \mathrm{SE})$ than reefs $(1.0 \% \pm 0.6 \mathrm{SE})$.

Orientation affected the cover of some invertebrates and algae. The contrasting effect of orientation on spirorbids and serpulids is described above. Conopeum seurati was more abundant on vertical than horizontal surfaces on reefs and pontoons at only 1 site (Fig. 2c). Cryptosula pallasiana and barnacles (Balanus variegatus) typically were most abundant on horizontal undersides, but never at all sites or in each position (Figs. $2 b$, $3 b$, Table $3: b, h)$. The covers of some algae differed between orientations; Feldmania sp. and Cladophorales were more abundant on vertical surfaces than horizontal undersides (Fig. 3c,d, Table 3: i,j). Encrusting Dictyotalean algae were rare, but present only on vertical surfaces at all sites (reef: $1.6 \% \pm 0.5 \mathrm{SE}$, pontoon: $1.7 \% \pm 1.2 \mathrm{SE}$ ).

\section{DISCUSSION}

This study provides experimental evidence that pontoons in sheltered embayments are fundamentally different habitats from adjacent natural rocky reefs. The 
results are consistent with previous work (Connell \& Glasby 1999, Glasby 1999a) which showed that the dominant taxa on sheltered rocky reefs in Sydney are spirorbid polychaetes, red filamentous algae and encrusting bryozoans, whereas pontoons tend to be dominated by serpulid polychaetes, bryozoans and barnacles. These results and others (Connell 1999, Glasby 2000) suggest that the large differences reported previously between sessile assemblages on reefs and pontoons were likely to be due to differences in position (e.g. depth and/or proximity to the seafloor). Although physical attributes of substrata can influence the development of epibiotic assemblages, such differences did not play a role in the present study because identical settlement panels were used on reefs and pontoons. Clearly, the addition of pontoons to waterways may affect the distributions and abundances of sessile organisms (and possibly many other types of organisms: Glasby \& Connell 1999) because they constitute new subtidal habitats. This prospect has important ramifications for the ever-increasing urbanization of coastal regions.

More generally, the present study demonstrated clear and remarkably consistent differences between newly developed epibiotic assemblages on vertical surfaces and horizontal undersides. Furthermore, assemblages on vertical and horizontal surfaces attached to pontoons were different from assemblages on corresponding surfaces attached to reefs. Thus, it could be considered that pontoons actually introduce 2 new habitats into waterways - vertical sides and horizontal undersurfaces. Many researchers have shown that different assemblages develop on surfaces of different orientations (e.g. Pomerat \& Reiner 1942, Lilly et al. 1953, Buss 1979, Harris \& Irons 1982, Todd \& Turner 1986, Hurlbut 1991a). The reasons for such differences are not clear, but may involve factors such as light (Kennelly 1989, Baynes 1999, Glasby 1999c), predation/grazing (Mook 1981, Keough \& Downes 1982, Breitburg 1985, Osman et al. 1992), larval behaviour (Meadows \& Campbell 1972, Raimondi \& Keough 1990, Hurlbut 1991b) and water flow at micro- or meso-scales (Eckman 1983, Mullineaux \& Garland 1993, Breitburg et al. 1995, Guichard \& Bourget 1998).

Not all the results of the present study were as predicted. There were very large differences between panels positioned on reefs and pontoons but, in general, interactions were not detected between position and orientation. That is, for most taxa, the differences between vertical and horizontal panels were comparable in the 2 positions. Other than taxa which were rare in 1 of the positions, the only interaction detected was for serpulid polychaetes. Serpulids were more abundant on horizontal undersides than vertical panels on reefs, but there was no effect of orientation for panels attached to pontoons (Fig. 3a). Pomerat \& Reiner (1942) reported similar results for panels that were positioned on the seafloor, rather than being attached to floating structures. Comparisons of assemblages on settlement panels suspended from the surface of the water and panels fixed to the seafloor have rarely been made. The few data available are, however, consistent with the results of the present study in that barnacles (Balanus spp.), bryozoans (especially Bugula spp.) and some sponges tend to be more abundant on suspended substrata, whereas algae are more abundant on fixed substrata (Fuller 1946, Withers \& Thorp 1977). Keough (1984) also reported greater recruitment of bryozoans on panels attached to pilings (positioned metres from the seafloor) than on panels on the seafloor (amongst the bivalve Pinna bicolor). He suggested that this was due to the limited dispersal of bryozoan larvae and the fact that there were denser populations of adults on pilings than in $P$. bicolor beds.

It is surprising that, despite extensive evidence of effects of orientation on the development of epibiotic assemblages, few researchers justify their choice of orientation of settlement panels. Some do, and it is generally to mimic another substratum (either natural or artificial) to ensure that direct comparisons can be made (e.g. Kennelly 1983, Keough 1983, Butler 1986, Todd \& Turner 1986, McGuinness 1989). It seems that orientation may often be chosen to maximise the diversity or biomass of assemblages and/or to minimise effects of sedimentation. That is, panels are often orientated horizontally and the shaded undersides are examined. It was noted over $60 \mathrm{yr}$ ago that the shaded undersides of surfaces often had more luxuriant growth than vertical or unshaded surfaces (Visscher 1927, Coe \& Allen 1937). Moreover, it was observed that many sessile organisms settle in large abundances on floating surfaces (Grave 1933), and subsequently it has become common to attach settlement panels to floating rafts or pontoons (e.g. Wisely 1959, Osman 1977, Russ 1977, Sutherland \& Karlson 1977, Greene \& Schoener 1982, Hurlbut 1991c, Bourget et al. 1994, Osman \& Whitlatch 1995). This study has demonstrated that the information obtained from floating settlement panels is unlikely to be directly comparable to assemblages on fixed natural hard substrata. In fact, even if settlement panels are fixed to pilings many metres from the seafloor (another common method of deployment), they are likely to develop very different assemblages from those on natural hard substrata close to the seafloor (Glasby 1999b). It should be noted, however, that the present experiment was run for only $7 \mathrm{mo}$ and it is possible that different conclusions could have been drawn from a longer-term study.

The generality of many of the findings from the early 'fouling' studies is yet to be determined, and it is not 
known to what extent we can extrapolate from artificial floating habitats to natural fixed, subtidal, hard substrata. Certainly, some specific processes will be similar, if not identical, across these habitats, but it is perhaps time that we began to test hypotheses about epibiota in more natural habitats. Knowledge about assemblages on artificial structures certainly is useful, especially as structures continue to be added to marine environments (Glasby \& Connell 1999), but we need also to understand the natural processes that structure these assemblages and any potential impacts to naturally occurring assemblages. Surprisingly, few studies of subtidal epibiota have attached settlement panels directly to, or in positions similar to, natural hard substrata (for counter-examples see Harlin \& Lindbergh 1977, Keough \& Downes 1982, Kennelly 1983, Hixon \& Brostoff 1985, Todd \& Turner 1986, McGuinness 1989, Glasby \& Underwood 1998). Admittedly, the way panels were attached to reef in the present study may have resulted in some differences between assemblages on panels and the adjacent reef (Osman 1982). The panels were not integral with the substratum, which could have affected access by predators and therefore growth of epibiota (e.g. Harris \& Irons 1982, Breitburg 1985). This method of attachment was, however, comparable to that for panels on pontoons which were also potentially isolated from certain predators because they were not in direct contact with the surface of the pontoon (and were of course many metres from the reef).

We do not yet fully understand why pontoons are such different habitats from natural rocky reefs, but their floating nature, distance from the seafloor, and degree of shading are likely to play major roles (Glasby 1999b). Regardless of the reason for any differences, the fact is that they are different and this may have implications for many studies involving settlement panels. Furthermore, the prevalence of artificial 'pontoon habitats' in waterways around the world should be of concern to ecologists. Very little research has investigated the potential impacts that assemblages on these artificial habitats may have on marine organisms in natural habitats, but there are many conceivable direct and indirect effects (Glasby \& Connell 1999). One of the most likely is that pontoons may influence the dispersal of native and exotic species of marine organisms by providing stepping stones and allowing colonisation of previously inaccessible areas. It is noteworthy that, in the present study, the exotic invertebrates Styela plicata and Bugula neritina tended to be more abundant on pontoons than on rocky reefs.

It often has been noted that the assemblages that develop on artificial surfaces may be different from those on natural substrata because of intrinsic properties of the surfaces (e.g. Coe 1932, Jackson 1977, Osman 1977, Kennelly 1983, Keough 1983). This study has shown that the positioning of the surface also may have considerable effects on the development of assemblages. Researchers must be aware of the many possible limitations of using artificial surfaces to test hypotheses about naturally occurring assemblages, particularly when surfaces are deployed in artificial habitats. It is important that we attempt to determine to what extent we can extrapolate from artificial to natural habitats or begin to test more hypotheses using natural habitats.

Acknowledgements. This research was funded by the Centre for Research on Ecological Impacts of Coastal Cities (University of Sydney). We thank S. Heislers, G. Housefield and N. Knott for assistance in the field, Dr P. Kott for help with identifying Diplosoma listerianum, and A. J. Underwood and M. G. Chapman for useful discussion. The manuscript benefited from comments by M. Holloway, S. Kennelly, J. Tanner, C. Todd, A. Davis and an anonymous referee. Special thanks to T. Black for facilitating this research.

\section{LITERATURE CITED}

Aleem AA (1957) Succession of marine fouling organisms on test panels immersed in deep-water at la Jolla, California. Hydrobiologia 11:40-58

Baynes TW (1999) Factors structuring a subtidal encrusting community in the southern Gulf of California. Bull Mar Sci 64:419-450

Bell JD, Steffe AS, Westoby M (1985) Artificial seagrass: how useful is it for field experiments on fish and macroinvertebrates? J Exp Mar Biol Ecol 90:171-177

Bourget E, DeGuise J, Daigle G (1994) Scales of substratum heterogeneity, structural complexity, and the early establishment of a marine epibenthic community. J Exp Mar Biol Ecol 181:31-51

Box GEP (1953) Non-normality and tests on variances. Biometrika 40:318-335

Breitburg DL (1985) Development of a subtidal epibenthic community: factors affecting species composition and the mechanisms of succession. Oecologia 65:173-184

Breitburg DL, Palmer MA, Loher T (1995) Larval distributions and the spatial patterns of settlement of an oyster reef fish: responses to flow and structure. Mar Ecol Prog Ser 125: 45-60

Brown KM, Swearingen DC (1998) Effects of seasonality, length of immersion, locality and predation on an intertidal fouling assemblage in the Northern Gulf of Mexico. J Exp Mar Biol Ecol 225:107-121

Buss LW (1979) Habitat selection, directional growth and spatial refuges: why colonial animals have more hiding places. In: Larwood G, Rosen BR (eds) Biology and systematics of colonial organisms. Academic Press, London, p 459-497

Butler AJ (1986) Recruitment of sessile invertebrates at five sites in Gulf St. Vincent, South Australia. J Exp Mar Biol Ecol 97:13-36

Butler AJ, Connolly RM (1996) Development and long term dynamics of a fouling assemblage of sessile marine invertebrates. Biofouling 9:187-209

Butler MA, Rotella JJ (1998) Validity of using artificial nests to assess duck-nest success. J Wildl Manag 2:163-171

Choat JH, Kingett PD (1982) The influence of fish predation 
on the abundance cycles of an algal turf invertebrate fauna. Oecologia 54:88-95

Clarke KR, Green RH (1988) Statistical design and analysis for a 'biological effects' study. Mar Ecol Prog Ser 46: 213-226

Coe WR (1932) Season of attachment and rate of growth of sedentary marine organisms at the pier of the Scripps Institution of Oceanography, La Jolla, California. Bull Scripps Inst Oceanogr Univ Calif Tech Ser 3:37-86

Coe WR, Allen WE (1937) Growth of sedentary marine organisms on experimental blocks and plates for nine successive years at the pier of the Scripps Institution of Oceanography. Bull Scripps Inst Oceanogr Univ Calif Tech Ser 4: 101-136

Connell SD (1999) Effects of surface orientation on the cover of epibiota. Biofouling 14:219-226

Connell SD (2000) Floating pontoons create novel habitats for subtidal epibiota. J Exp Mar Biol Ecol 247:183-194

Connell SD, Glasby TM (1999) Do urban structures influence local abundance and diversity of subtidal epibiota? A case study from Sydney Harbour, Australia. Mar Environ Res 47:373-387

Dean TA, Hurd LE (1980) Development in an estuarine fouling community: the influence of early colonists on later arrivals. Oecologia 46:295-301

Doherty PJ, Fowler AJ (1994) Demographic consequences of variable recruitment to coral reef fish populations: a congeneric comparison of two damselfishes. Bull Mar Sci 54: 297-313

Downes BJ, Lake PS, Schreiber ESG, Glaister A (1998) Habitat structure and regulation of local species diversity in a stony upland stream. Ecol Monogr 68:237-257

Eckman JE (1983) Hydrodynamic processes affecting benthic recruitment. Limnol Oceanogr 28:241-257

Eggleston DB, Lipcius RN, Grover JJ (1997) Predator and shelter-size effects on coral reef fish and spiny lobster prey. Mar Ecol Prog Ser 149:43-59

Fuller JL (1946) Season of attachment and growth of sedentary marine organisms at Lamoine, Maine. Ecology 27:150-158

Glasby TM (1998) Estimating spatial variability in developing assemblages of epibiota on subtidal hard substrata. Mar Freshw Res 49:429-437

Glasby TM (1999a) Differences between subtidal epibiota on pier pilings and rocky reefs at marinas in Sydney, Australia. Estuar Coast Shelf Sci 48:281-290

Glasby TM (1999b) Interactive effects of shading and proximity to the seafloor on the development of subtidal epibiotic assemblages. Mar Ecol Prog Ser 190:113-124

Glasby TM (1999c) Effects of shading on subtidal epibiotic assemblages. J Exp Mar Biol Ecol 234:275-290

Glasby TM (2000) Surface composition and orientation interact to affect subtidal epibiota. J Exp Mar Biol Ecol 248: $177-190$

Glasby TM, Connell SD (1999) Urban structures as marine habitats. Ambio 28:595-598

Glasby TM, Underwood AJ (1998) Determining positions for control locations in environmental studies of estuarine marinas. Mar Ecol Prog Ser 171:1-14

Grave BH (1933) Rate of growth, age at sexual maturity, and duration of life of certain sessile organisms, at Woods Hole, Massachusetts. Biol Bull 65:375-386

Greene CH, Schoener A (1982) Succession on marine hard substrata: a fixed lottery. Oecologia 55:289-297

Guichard F, Bourget E (1998) Topographic heterogeneity, hydrodynamics, and benthic community structure: a scaledependent cascade. Mar Ecol Prog Ser 171:59-70

Harlin MM, Lindbergh JM (1977) Selection of substrata by seaweeds: optimal surface relief. Mar Biol 40:33-40

Harris LG, Irons KP (1982) Substrate angle and predation as determinants in fouling community succession. In: Cairns J (ed) Artificial substrates. Ann Arbor Science, Michigan, p 131-174

Hixon MA, Brostoff WN (1985) Substrate characteristics, fish grazing, and epibenthic reef assemblages off Hawaii. Bull Mar Sci 37:200-213

Holbrook SJ, Schmitt RJ, Ambrose RF (1990) Biogenic habitat structure and characteristics of temperate reef fish assemblages. Aust J Ecol 15:489-503

Huhta E, Jokimaki J, Helle P (1998) Predation on artificial nests in a forest dominated landscape - the effects of nest type, patch size and edge structure. Ecography 21: $464-471$

Hurlbut CJ (1991a) The effects of larval abundance, settlement and juvenile mortality on the depth distribution of a colonial ascidian. J Exp Mar Biol Ecol 150:183-202

Hurlbut CJ (1991b) Larval substratum selection and postsettlement mortality as determinants of the distribution of two bryozoans. J Exp Mar Biol Ecol 147:103-119

Hurlbut CJ (1991c) Community recruitment: settlement and juvenile survival of seven co-occuring species of sessile marine invertebrates. Mar Biol 109:507-515

Jackson JBC (1977) Habitat area, colonization, and development of epibenthic community structure. In: Keegan BF, Ceidigh PO, Boaden PJS (eds) Biology of benthic organisms. Pergamon Press, London, p 349-358

Jones GP (1991) Postrecruitment processes in the ecology of coral reef fish populations: a multifactorial perspective. In: Sale PF (ed) The ecology of fishes on coral reefs. Academic Press, San Diego, p 294-328

Kay AM, Keough MJ (1981) Occupation of patches in the epifaunal communities on pier pilings and the bivalve Pinna bicolour at Edithburgh, South Australia. Oecologia 48: 123-130

Kennelly SJ (1983) An experimental approach to the study of factors affecting algal colonization in a sublittoral kelp forest. J Exp Mar Biol Ecol 68:257-276

Kennelly SJ (1989) Effects of kelp canopies on understorey species due to shade and scour. J Exp Mar Biol Ecol 50: 215-224

Keough MJ (1983) Patterns of recruitment of sessile invertebrates in two subtidal habitats. J Exp Mar Biol Ecol 66: 213-245

Keough MJ (1984) Effects of patch size on the abundance of sessile marine invertebrates. Ecology 65:423-437

Keough MJ, Downes BJ (1982) Recruitment of marine invertebrates: the role of active larval choices and early mortality. Oecologia 54:348-352

King DI, DeDraaf RM, Griffin CR, Maier TJ (1999) Do predation rates on artificial nests accurately reflect predation rates on natural bird nests? J Field Ornithol 70:257-262

Lilly SJ, Sloane JF, Bassindale R, Ebling FJ, Kitching JA (1953) The ecology of the Lough Ine rapids with special reference to water currents. IV. The sedentary fauna of sublittoral boulders. J Anim Ecol 22:87-96

McDougall KD (1943) Sessile marine invertebrates of Beaufort, North Carolina. Ecol Monogr 13:321-374

McGuinness KA (1989) Effects of some natural and artificial substrata on sessile marine organisms at Goleta Reef, Panama. Mar Ecol Prog Ser 52:201-208

Meadows PS, Campbell JI (1972) Habitat selection by aquatic invertebrates. Adv Mar Biol 10:271-382

Mook DH (1981) Effects of disturbance and initial settlement on fouling community structure. Ecology 62:522-526

Mullineaux LS, Garland ED (1993) Larval recruitment in 
response to manipulated field flows. Mar Biol 116:667-683

Nour N, Matthysen E, Dhondt AA (1993) Artifical nest predation and habitat fragmentation-different trends in bird and mammal predators. Ecography 16:111-116

Osman RW (1977) The establishment and development of a marine epifaunal community. Ecol Monogr 47:37-63

Osman RW (1982) Artifical substrates as ecological islands. In: Cairns J (ed) Artificial substrates. Ann Arbor Science, Michigan, p 71-114

Osman RW, Whitlatch RB (1995) The influence of resident adults on recruitment: a comparison to settlement. J Exp Mar Biol Ecol 190:169-198

Osman RW, Whitlatch RB, Malatesta RJ (1992) Potential role of micro-predators in determining recruitment into a marine benthic community. Mar Ecol Prog Ser 83:35-43

Paradise CJ (1998) Colonisation and development of insects in simulated treehole habitats with distinct resource and $\mathrm{PH}$ regimes. Ecoscience 5:9-45

Pomerat CM, Reiner ER (1942) The influence of surface angle and of light on the attachment of barnacles and other sedentary organisms. Biol Bull 82:14-25

Raimondi PT, Keough MJ (1990) Behavioural variability in marine larvae. Aust J Ecol 15:427-437

Reading CJ (1997) A proposed standard method for surveying reptiles on dry lowland heath. J Appl Ecol 34:1057-1069

Russ GR (1977) A comparison of the marine fouling occurring at the two principal Australian naval dockyards. Department of Defence, Australia, Melbourne, Victoria

Schmidt GH, Warner GF (1984) Effects of caging on the

Editorial responsibility: Tony Underwood (Contributing Editor), Sydney, New South Wales, Australia development of a sessile epifaunal community. Mar Ecol Prog Ser 15:251-263

Sutherland JP (1974) Multiple stable points in natural communities. Am Nat 108:859-873

Sutherland JP, Karlson RH (1977) Development and stability of the fouling community at Beaufort, North Carolina. Ecol Monogr 47:425-446

Todd CD, Turner SJ (1986) Ecology of intertidal and sublittoral cryptic epifaunal assemblages. I. Experimental rationale and the analysis of larval settlement. J Exp Mar Biol Ecol 99:199-231

Underwood AJ (1981) Techniques of analysis of variance in experimental marine biology and ecology. Annu Rev Oceanogr Mar Biol 19:513-605

Underwood AJ, Kingsford MJ, Andrew NL (1991) Patterns in shallow subtidal marine assemblages along the coast of New South Wales. Aust J Ecol 6:231-249

Visscher JP (1927) Nature and extent of fouling of ships' bottoms. Bull Bur Fish Wash 43:193-252

Wilson OT (1925) Some experimental observations of marine algal successions. Ecology 6:303-311

Wisely B (1959) Factors influencing the settling of the principal marine fouling organisms in Sydney Harbour. Aust J Mar Freshw Res 10:30-44

Withers RG, Thorp CH (1977) Studies on the shallow, sublittoral epibenthos of Langstone Harbour, Hampshire, using settlement panels. In: Keegan BF, Ceidigh PO, Boaden PJS (eds) Biology of benthic organisms. Pergamon Press, London, p 595-604

Submitted: February 16, 2000; Accepted: September 29, 2000 Proofs received from author(s): March 22, 2001 